\title{
Women, Media and Politics
}

\section{Heather Savigny and Candida Yates}

As the pages of this journal attest, there is a necessary, wide ranging literature in political science that discusses the representation of women in politics (Lovenduski, 2005; Campbell, 2005); descriptively (Dahlerup and Freidenvall, 2005) substantively (Childs, 2002; Celis and Childs, 2008) intersectionally (Mügge and de Jong, 2013; Ward, 2017) and as political activists (Evans, 2015). In political science more widely, the literature tends to assume that Parliament is the site where politics takes place. This special section argues that media are also a crucial site where politics is enacted. To understand Parliamentary politics and policy, the section contends, we must draw on insights in to how media mediate political discourse and function politically. In drawing together this range of debates, this special section operates with an expansive definition of politics (drawing on feminist approaches) and argues we need to take seriously the role that media play in disseminating the actions, behaviours and policies of political elites. Media, crucially, provide the wider discursive context in which politicians and citizens learn about, and make sense of politics. In this sense, the section draws attention to the active role the media play in shaping how gender informs expectations of how male and female politicians 'should' behave. Exposing this interactive relationship between media and politics, enables us to reflect further on the ways in which gendered power relations become embedded within the political psyche.

As such, the papers in this section argue that we need to recognise the active role that media play not just in the political process, but in the shaping and structuring of gendered political relationships. Empirically, Karen Ross, Marloes Jansen, and Lidwien van de Wijngaer discuss how the rise of social media has enabled female politicians to be more visible than traditionally male dominated media platforms have previously allowed. Their 
particular focus is how gender plays a role when politicians tweet about political issues. Their findings suggest that while women's styles of tweeting are more empathetic, men's use of twitter is more impersonal. However, as they suggest, gender is not the only determinant and their findings show party positioning plays a key role in the ways in which an issue is communicated to the public. In this sense, they argue for an understanding of the intertwining of gender and party as foci of analysis in empirical political communication. We then move to two conceptual papers. In her interdisciplinary analysis that introduces a new psycho-political methodology, Candida Yates demonstrates the ways in which emotions are increasingly discursively evoked to elicit political support or rejection of politicians. Yates argues that this emotional mobilisation takes place along gender lines and she uses a case study of Theresa May in order to explore the anxieties that are often stirred up through media representations of female political leaders. In her analysis of media discourses about May, she illustrates how gender stereotypes about femininity, emotion and the body are evoked in order to 'punish' May for failing to conform to normative perceptions of embodied femininity and political leadership. Following on conceptually in unpacking gendered mediated political discourses, Heather Savigny and Richard Scullion argue that to understand the ways in which women are positioned politically relies on an understanding of the ways in which femininity and masculinity are constructed in opposition to, and in interdependence, with each other through media discourse. Using UK austerity policy to illustrate their argument, they reflect on the ways in which gendered powered structures are embedded in and through the ways in which wealth creation is masculinised and austerity feminised. This in turn, they argue, means that media discourses operate politically in the reinforcement of the gendered violence which underpins successive UK government's austerity policies.

The articles in this special section on Women, Media and Politics adopt a broad definition of politics which focuses attention on the ways in which all relations of power are 
political, and crucially, we argue, we also need to make sense of the ways in which these power relations are mediated. A key aspect of the research presented here is that media offer a re-presentation of reality/ies, and that the ways in which women are represented is descriptively and /or substantively needs to be combined with an analysis that unpacks the underlying power structures or relations which shape this representation. Media technologies have the capacity to both perpetuate existing power structures and/or challenge them, and so to this end, women can be analysed as objects, subjects, or active agents. As the articles in this special section argue in different ways, the affective, ideological and discursive power of such processes in shaping the politics of gender and the lived realities of women should not be underestimated. To this end, we argue that we need to take not just women seriously in our analysis (cf. Enloe, 2013) but also the active role that media play in sustaining gendered power relationships which is manifested in and through the processes of Parliamentary politics and policy and its systems of communication.

Campbell, R., Childs, S. \& Lovenduski, J. 2014, Deeds and words: gendering politics after Joni Lovenduski, .

Celis, K. \& Childs, S. 2008, "Introduction: The Descriptive and Substantive Representation of Women: New Directions", Parliamentary Affairs, vol. 61, no. 3, pp. 419-425.

Childs, S. 2002, "Concepts of Representation and the Passage of the Sex Discrimination (Election Candidates) Bill", The Journal of Legislative Studies, vol. 8, no. 3, pp. 90-108.

Drude Dahlerup \& Lenita Freidenvall 2005, "Quotas as a 'fast track' to equal representation for women", International Feminist Journal of Politics, vol. 7, no. 1, pp. 26-48. 
Enloe, C.H. 2013, Seriously! : investigating crashes and crises as if women mattered, University of California Press, Berkeley, Calif.

Evans, E. 2015, The Politics of Third Wave Feminisms - Neoliberalism, Intersectionality, and the State in Britain and the US, Palgrave, Basingstoke.

Lovenduski, J. 2005, Feminizing politics, Polity, Oxford; Malden, MA.

Mügge, L. \& Jong, S.d. 2013, 'Intersectionalizing European politics: bridging gender and ethnicity", Politics, Groups, and Identities, vol. 1, no. 3, pp. 380-389.

Ward, O. 2017, "Intersectionality and Press Coverage of Political Campaigns", The International Journal of Press/Politics, vol. 22, no. 1, pp. 43-66. 